Journal of Biotechnology and Strategic Health Research

\author{
Research Article/ Araștırma Makalesi \\ http://dergipark.org.tr/tr/pub/bshr
}

\title{
The Effect of Covid-19 On Emergency Surgical Cases. Data From A High-Volume City
}

\section{Covid-19’un Acil Cerrahi Vakalar Üzerindeki Etkisi. Yüksek Hacimli Şehirden Veriler}

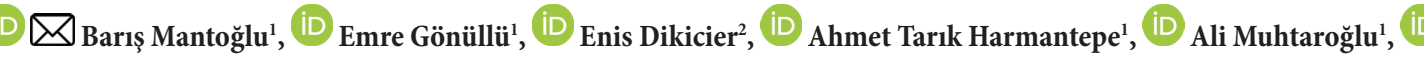

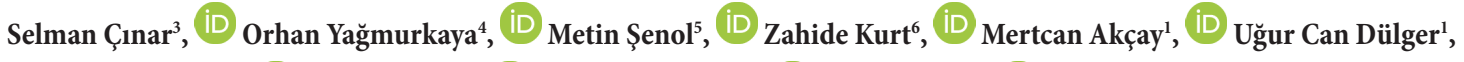
(iD) Zülfüi Bayhan², (iD Fatih Altıntoprak ${ }^{2}$, (D) Belma Koçer², iD Fehmi Çelebi²
}

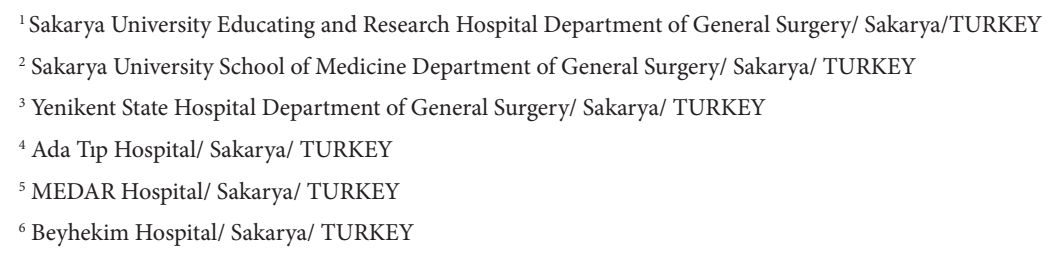




\section{INTRODUCTION}

When COVID 19 was first described, ${ }^{1,2}$ we were unable to foresee the serious health problems it would create. In our country, rapid action was taken against the virus, and various necessary measures and arrangements were provided. As a result of the seriousness and rapid progression of the pandemic, healthcare administrators have concentrated their health resources on this issue in terms of humans and medication. Changes in general surgical practice were inevitably adopted quickly. Some centers postponed elective surgery procedures and only performed surgery for exceptional cancer cases, which could have been disadvantageous to patients. Emergency surgical cases have been carried out during the pandemic according to the guidelines of the national surgical associations as well as many leading international communities. ${ }^{3,8}$ This study aimed to ascertain the diversity and variation in the number of emergency surgery procedures performed during the pandemic in hospitals in our city during the acute phase of the pandemic.

\section{MATERIAL and METHODS}

In this multicenter retrospective study, the acute phase period of the pandemic in our country (Mid-March 2020mid-May 2020) and the non-pandemic 2-month period (January 2020-February 2020) were the dates of the study. Emergency surgical procedures performed during the two periods at third (Sakarya University Educating and Research Hospital) and second level public (Yenikent State Hospital) and private (Ada Tip Hospital, MEDAR Hospital, Beyhekim Hospital) health institutions in Sakarya Province were included in this study. The distributions of age and gender, as well as the type and number of emergency procedures performed in the general surgery clinics of our city during the two periods, were evaluated. The urgent surgeries were collected under eight main headings. These titles are described in detail in Table 2. The statistical analysis was performed using SPSS version 25 (SPSS Inc., Chicago, IL, USA). Numerical variables are presented as mean \pm standard deviation. Categorical variables are pre- sented as counts and percentages. The Shapiro-Wilk test was used to determine whether the variables were normally distributed. The Wilcoxon signed-rank test was used for nonparametric dependent samples. Student's t-test was used to compare independent parametric groups. A p-value $<0.05$ was considered significant. Ethics committee approval was obtained from the Sakarya University Ethics Committee and the Ministry of Health, General Directorate of Health Services.

\section{RESULTS}

The distribution of patients before the pandemic by gender was $53.1 \%$ male and $46.9 \%$ female; it was $61.6 \%$ male and $38.4 \%$ female during the pandemic. The mean age of the patients undergoing emergency surgery was $54.72 \pm 3.65$ years before the pandemic and $38.54 \pm 2.32$ years during the pandemic ( $\mathrm{p}<0.05)$. A total of 114,473 patients were admitted to the emergency departments of all branches before the pandemic, and 46,006 were admitted during the pandemic period. During the 2 months before the pandemic, 290 emergency surgeries were performed, while during the acute pandemic period, 164 emergency operations were performed during the same time interval ( $p=$ 0.012) (Table 1). Surgery during the pre-pandemic period was performed mostly for acute appendicitis (44.48\%) followed by other operations (15.51\%), strangulated hernia (10.35\%), acute cholecystitis (9.66\%), tumor ileus (7.25\%), non-tumor ileus $(5.51 \%)$, perforation $(4.82 \%)$, and trauma-related (2.42\%) surgeries (Figure 1). Acute appendicitis $(57.32 \%)$ was the most common reason for a surgical procedure during the acute phase of the pandemic, followed by other operations (11.58\%), acute cholecystitis (11.54\%), non-tumor ileus (6.7\%), strangulated hernia $(4.87 \%)$, tumor ileus $(3.67 \%)$, perforations $(3.1 \%)$, and trauma-related surgeries (1.22\%) (Figure 2). 
J Biotechnol and Strategic Health Res. 2021;5(1):65-70

MANTOĞLU et al., Covid-19 and Emergency Surgery

Table 1- Change rates and the count of cases before and after pandemic

\begin{tabular}{|l|c|c|c|}
\hline Cases & $\begin{array}{c}\text { Before } \\
\text { Pandemic }\end{array}$ & $\begin{array}{c}\text { During } \\
\text { Pandemic }\end{array}$ & $\begin{array}{c}\text { Rate of } \\
\text { change }\end{array}$ \\
\hline Acute Appendicitis & 129 & 94 & $-27 \%$ \\
\hline Acute Cholecystitis & 28 & 19 & $-32 \%$ \\
\hline Strangulated Hernia & 30 & 8 & $-73 \%$ \\
\hline Trauma & 7 & 2 & $-71 \%$ \\
\hline Tumor Ileus & 21 & 6 & $-71 \%$ \\
\hline Non-Tumor Ileus & 16 & 11 & $-31 \%$ \\
\hline Perforation & 14 & 5 & $-64 \%$ \\
\hline Other & 45 & 19 & $-58 \%$ \\
\hline Sum & 290 & 164 & $-43 \%$ \\
\hline Significance: $\mathrm{p}=0.01$ & & & \\
\hline
\end{tabular}

During Pandemic

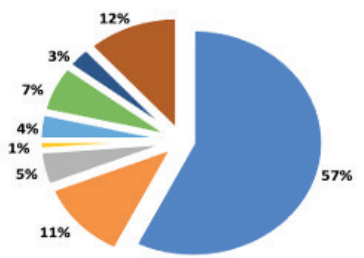

\footnotetext{
- Acute Appendicitis = Acute Cholecyst itis = Strangulated Hernia

= Trauma $\quad$ - Tumor lleus $\quad$ Non-Tumor lleus

- Perforation $\quad$ - Other
}

Figure 1: Percentage distribution of cases during pandemic

\section{Before Pandemic}

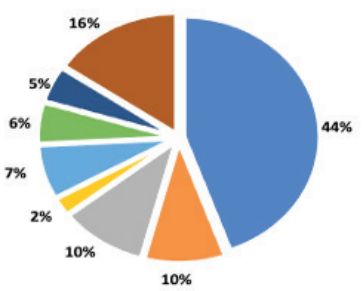

- Acute Appendicitis = Acute Cholecystitis = Strangulated Hernia

$$
\text { = Trauma = Tumor lleus = Non-Tumorlleus }
$$

- Perforation

\begin{tabular}{|c|c|c|c|c|}
\hline \multicolumn{3}{|c|}{ Before Pandemic } & \multicolumn{2}{|l|}{ During Pandemic } \\
\hline & $\mathrm{n}$ & percent & $\mathrm{n}$ & percent \\
\hline Appendicitis & Laparoscopic (119), Open (10) & $44.48 \%$ & Laparoscopic (34), Open (60) & $57.32 \%$ \\
\hline Cholecystitis & Laparoscopic (27), Open (1) & $9.66 \%$ & Laparoscopic (17), Open (2) & $11.54 \%$ \\
\hline Hernia & $\begin{array}{l}\text { Umbilical (7), Incisional (8), } \\
\text { Inguinal (13), TAPP (2). }\end{array}$ & $10.35 \%$ & Umbilical (1), Incisional (0), Inguinal (7), TAPP (0 & $4.87 \%$ \\
\hline Trauma & $\begin{array}{l}\text { Gunshot (1), Sharp (2), Blunt } \\
\text { (splenectomy (3), Diaphragm injury (1) ) }\end{array}$ & $2.42 \%$ & $\begin{array}{l}\text { Gunshot (0), Sharp (1),Blunt } \\
\text { (splenectomy (1), Diaphragm injury (0)) }\end{array}$ & $1.22 \%$ \\
\hline Tumor Ileus & $\begin{array}{l}\text { Right Colon (11), Left Colon (4), } \\
\text { Rectosigmoid (6) }\end{array}$ & $7.25 \%$ & $\begin{array}{c}\text { Right Colon (2), Left Colon (3) } \\
\text { Rectosigmoid (1) }\end{array}$ & $3.67 \%$ \\
\hline Non-Tumor Ileus & Brid (4), Bezoar (8), Volvulus (4) & $5.51 \%$ & Brid (9), Bezoar (1), Volvulus (1) & $6.7 \%$ \\
\hline Perforation & $\begin{array}{c}\text { Gastric (peptic ulcer lap.(7) open (2)), } \\
\text { Small intestine (3),Colon (diverticular) (2) }\end{array}$ & $4.82 \%$ & $\begin{array}{c}\text { Gastric (peptic ulcer open (2)), } \\
\text { Small intestine, (0) Colon (diverticular) (1) }\end{array}$ & $3.1 \%$ \\
\hline Other & $\begin{array}{c}\text { Mesenteric ischemia (8), Giant goiter (1) } \\
\text { Fournier gangrene (3) Perianal abscess (24) } \\
\text { Pyloric stenosis (2) Diagnostic laparoscopy (7) }\end{array}$ & $15.51 \%$ & $\begin{array}{c}\text { Mesenteric ischemia (0) Giant goiter }(0) \\
\text { Fournier gangrene (3), Perianal abscess (15), } \\
\text { Pyloric stenosis (0), Diagnostic laparoscopy (0) }\end{array}$ & $11.58 \%$ \\
\hline Sum & 290 & $100 \%$ & 164 & $100 \%$ \\
\hline \multicolumn{5}{|c|}{ TAPP: Trans-Abdominal Pre-Peritoneal Lap: laparoscopy } \\
\hline
\end{tabular}

- Other

Figure 2: Percentage distribution of cases before pandemic 


\section{DISCUSSION}

The COVID 19 outbreak is an unprecedented health problem, and healthcare systems did not initially realize the large number of resources needed for this unexpected situation. Medical staff and equipment were promptly focused on the rapid spread of the epidemic and the necessity for hospitalization. Several centers in our country suspended elective surgical procedures, as did the rest of the world. Priority was given to patients who required cancer surgery and surgeries that could not be postponed. Covid-19 has also had critical effects on surgery in this province. Our hospital and all of its employees were commissioned for the pandemic, as it is the only third-level health facility in our city. Emergency surgical cases are normally carried out at second-level private and public hospitals and all deferrable elective cases were postponed. Outflow from the province was prohibited by the Ministry of Health.

Emergency surgical procedures were commenced under extreme conditions and with differences in approach. Emergency surgical interventions were performed on COVID-19 patients, with all precautions undertaken according to the guidelines. ${ }^{9}$ The number of admissions to emergency departments decreased as did the number of cases requiring emergency surgery. ${ }^{10,11}$ We have experienced a significant decrease in the number of admissions to the emergency department during the pandemic (Table 1). The reasons include the curfew restriction recommended by the Ministry of Health and the fact that patients would rather not visit the hospital for complaints to avoid infection with the virus.

Cases requiring urgent surgical intervention were generally reduced. ${ }^{12,13}$ Although both national and international centers have addressed this issue, no study has explained the reason. There was a marked reduction in all emergency surgery indications in our city. While there may be a rational explanation for the decrease in some diseases due to the pandemic, it does not explain the decrease in other surgical cases. The decrease in the numbers of acute appendicitis and acute cholecystitis cases may have been affected by the change in dietary habits caused by the ban on leaving home. Similarly, as non-operative management ${ }^{14,15}$ of such cases may be possible, medical follow-up may be favored by physicians during the acute phase of the pandemic. Similarly, social isolation and a lack of mobility are among the factors for a reduction in the number of incarcerated hernia and trauma cases (vehicle, inside or outside injuries, gunshot wounds, cutting, and penetrating mechanism injuries). However, Valderrama et al. reported an increase in the number of strangulated inguinal hernia cases during the pandemic. ${ }^{13}$ The limitations and changes in life habits mentioned above may have caused a decrease in the incidence rates of non-tumor ileus. Nevertheless, it does not explain the dramatic decrease in the frequency of incidence of tumor-related intestinal obstructions and mesenteric ischemia following a few restrictions on social life. Some hypotheses can be proposed. These disease groups may have been infected with COVID 19, and their underlying and progressive diseases may have exacerbated COVID 19. Therefore, they may have been lost without being diagnosed with an underlying pathology. Furthermore, patients may have been unable to present at a hospital, so they attempted to solve their medical problems, and undesired outcomes may have been encountered. Nevertheless, the decrease in the number of cases requiring emergency surgery was statistically significant.

One of the limitations of our study is that of evaluating data from a single city. More detailed epidemiological studies should be carried out to investigate the reasons for the decrease in the number of patients. However, our study will be an important resource for similar studies to be carried out in the future.

\section{CONCLUSION}

The COVID 19 pandemic has affected all health systems in unexpected and unpredictable ways. As a result of a decreased number of cases, noted above, it may be that an increased number of acute and complex abdominal problems 
may present to emergency services soon. Therefore, we think that we should be well organized for the diagnosis and treatment of emergency general surgery cases in the second and perhaps the third wave of the pandemic. We believe that the studies to be carried out worldwide regarding this issue will have benefits.

\section{Availability of Data And Materials}

There is no additional data available to share with the readers.

The datasets used and/or analyzed during the current study are available from the corresponding author on reasonable request.

\section{Acknowledgements}

None

\section{Funding}

None

\section{Contributions}

BM: design, data collection, data analysis, interpretation, writing and revision. EG, ED, ZB: Data collection, data interpretation, and revision. BK, FC: Data analysis, interpretation, and writing. FA: Study design, interpretation and revision. ATH, AM, MA, UCD, SC, OY, MS, ZK: data collection, data interpretation, and revision. All authors read and approved the final manuscript.

\section{Ethics approval and consent to participate}

Sakarya University Ethics Committee has approved this research project. 71522473/050.01.04/280

\section{Competing interests}

The authors have no conflicts of interest. The authors are responsible for the content of the paper. 
J Biotechnol and Strategic Health Res. 2021;5(1):65-70

MANTOĞLU et al., Covid-19 and Emergency Surgery

\section{References}

1. Li X, Cui W, Zhang F. Who Was the First Doctor to Report the COVID-19 Outbreak in Wuhan, China? J Nucl Med. 2020;61(6):782-83.

2. N. Zhu et al. China Novel Coronavirus Investigating and Research Team. N Engl J Med. 2020;382(8):727-33.

3. American College of Surgeons Committee on Trauma. Maintaining Trauma Center Access and Care during the COVID-19 Pandemic: Guidance Document for Trauma Medical Directors. March 17. 2020; https://www.facs.org/covid-19/clinical-guidance/ maintaining-access.

4. European Association for Endoscopic Surgery. EAES and SAGES Recommendations Regarding Surgical Response To Covid-19 Crisis. Eur Assoc Endosc Surg Guidel. 2020; https://www.sages.org/recommendationssurgical-response-covid-19/.

5. Çolakoğlu MK, Öter V, Bostancı EB, Özmen MM, Sarıbeyoğlu K. Surgical management of digestive system cancers during the coronavirus disease 2019 pandemic: review of general suggestions. Turk J Surg 2020; 36 (2): 121-31.

6. Tao KX, Zhang BX, Zhang P, Zhu P, Wang GB, Chen XP. Recommendations for general surgery clinical practice in novel coronavirus pneumonia situation. Zhonghua Wai Ke Za Zhi. 2020; 58(3):170-77.

7. American College of Surgeons. COVID-19 : Recommendations for Management of Elective Surgical Procedures. American College of Surgeons. 2020. https://www.facs.org/ about-acs/covid-19/information-for-surgeons

8. Sezer A, Cicin İ, Karadeniz Çakmak G, Özkan Gürdal S, Bașaran G, Oyan B et al. Turkish national consensus on breast cancer management during temporary state of emergency due to COVID-19 outbreak. Turk J Surg. 2020;36(2):147-63.
9. Moletta L, Pierobon ES, Capovilla G, Costantini M, Salvador R, Merigliano S, et al. International guidelines and recommendations for surgery during Covid-19 pandemic: A Systematic Review. Int J Surg. 2020;79:180-88.

10. Patriti A, Eugeni E, Guerra F. What happened to surgical emergencies in the era of COVID-19 outbreak? Considerations of surgeons working in an Italian COVID-19 red zone. Updates Surg. 2020;72(2):309-10.

11. Berardi G, Levi Sandri GB, Colasanti M, Ettorre GM. Readaptation of surgical practice during COVID-19 outbreak: what has been done, what is missing and what to expect. $\mathrm{Br}$ J Surg. 2020;107(8):e251.

12. Patriti A, Baiocchi GL, Catena F, Marini P, Catarci M, Beatrice DV, et al. Emergency general surgery in Italy during the COVID-19 outbreak: First survey from the real life. World J Emerg Surg. 2020;15(1):36

13. Cano-Valderrama O, Morales X, Ferrigni CJ, Martín-Antona E, Turrado V, García A, et al. Reduction in emergency surgery activity during COVID-19 pandemic in three Spanish hospitals. Br J Surg. 2020;107(8):e239.

14. Podda M, Gerardi C, Cillara N, Fearnhead N, Gomes CA, Birindelli A, et al. Antibiotic treatment and appendectomy for uncomplicated acute appendicitis in adults and child ren: A systematic review and meta-analysis. Ann Surg. 2019;270(6):1028-40.

15. Di Saverio S, Sibilio A, Giorgini E, Biscardi A, Villani S, Coccolini F, et al. The NOTA study (non operative treatment for acute appendicitis): Prospective study on the efficacy and safety of antibiotics (amoxicillin and clavulanic acid) for treating patients with righ lower quadrant abdominal pain and long-term follow-up of conservatively treated suspected appendicitis. Ann Surg. 2014;260(1):109-17 